Article

\title{
Why Are Your Employees Leaving the Organization? The Interaction Effect of Role Overload, Perceived Organizational Support, and Equity Sensitivity
}

\author{
Cheol Young Kim ${ }^{1}$, Joo Han Lee ${ }^{2}$ and Soo Young Shin ${ }^{2, *}$ \\ 1 School of Business Administration, Myongji University, Seoul 15770020, Korea; cy0807.kim@gmail.com \\ 2 School of Business, Yeungnam University, Gyoengsan 38541, Korea; leejuhan82@gmail.com \\ * Correspondence: swim1@ynu.ac.kr; Tel.: +82-10-2383-1227
}

Received: 18 December 2018; Accepted: 23 January 2019; Published: 27 January 2019

check for updates

\begin{abstract}
Drawing on job demand-resources (JDR) theory, this study proposes that role overload and perceived organizational support have interaction effects on turnover intention. Further, we investigate the dynamics between role overload and turnover intention by considering differences in individuals' reactions to inequity. We conducted several hierarchical regression analyses to test our hypotheses using data from 207 team members at 12 manufacturing companies in South Korea. The results reveal a positive relationship between role overload and turnover intention and a significant joint moderation effect of perceived organizational support and equity sensitivity. This study expands on JDR theory by simultaneously considering the buffer and strain hypotheses in the role overload-turnover relationship and its link to equity sensitivity.
\end{abstract}

Keywords: role overload; turnover intention; perceived organizational support; equity sensitivity

\section{Introduction}

Previous studies on turnover intention have been undertaken based on the job demand-resources (JDR) model that job demands and job resources influence job strain outcomes [1,2]. Despite the many studies on job stress and turnover intention, little attention has been paid to the dynamics among job demand, resources, and turnover intention in the context of individual inclinations. The intention to exit varies among people experiencing similar stress situations [3]. This study applies the JDR model to social exchange while considering individual differences. One of the most important things about social exchange is equity [4]. Justice perception has a significant impact on turnover intention [5]. In this study, equity sensitivity is used as an individual inclination that changes employees' perception such as turnover intention. Equity sensitivity refers to individual responses to over-or under-reward situations [6,7]. Several studies have reported a negative relationship between role overload and justice perception based on the equity theory [8-10]. Employees with high equity sensitivity are highly responsive to changes in job demands and resources in their organization and seek to resolve any unfairness caused by role overload. They will try to acquire additional resources or reduce the demands to resolve injustices caused by role overload. This study predicts that employees who actively seek to resolve unfairness will have lower turnover intention than employees who tolerate the stress arising from unfairness caused by role overload.

Testing the interaction effect of role overload, perceived organizational support, and equity sensitivity on turnover intention allows for a more comprehensive examination than has yet been attempted in the turnover literature. This study advances the research on role stressors and turnover intention by jointly considering individual circumstances and personal traits to predict core employees' intention to leave their job. 


\section{Theoretical Framework and Hypothesis Development}

\subsection{Role Overload and Turnover Intention}

Stress is defined as a state of disequilibrium in the cognitive-emotional-environmental system [11]. According to the strain hypothesis [12], strenuous jobs that are high on demand and low on control can lead to psychosocial stress and burnout. Several studies have argued that employees under role-related stresses, such as role conflict, role ambiguity, and role overload, are more likely to become burned out. Role overload is a critical antecedent of job stress, as it dissipates resources [13]. Shultz, Wang, and Olson [14] reported that employees under role overload had the highest level of negative health outcomes. Karimi, Omar, Alipour, and Karimi [15] reported that role overload led to occupational stress. In addition, several previous studies reported that role overload negatively affected the attitudes and perceptions of employees [16].

Role stresses have been widely studied as antecedents of turnover intention [17]. For example, Cho, Choi, and Lee [18] reported the negative relationship between role stress and turnover intention in the airline industry. Shupe, Wambaugh, and Bramble [19] examined the negative effects of role stress on job satisfaction, job performance, and turnover intention, finding that role stress induced turnover intention. Based on JDR theory and the conservation of resources theory $[1,2]$, we expect that role overload will reduce employees' intention to remain with their organization as they continue to lose their cognitive and psychosocial resources. We thus propose the following:

Hypothesis 1. Role overload is positively related to turnover intention.

\subsection{Moderating Effect of Perceived Organizational Support (POS)}

Employers expect employees to dedicate themselves to the organization. They require employees to use their resources to pursue organizational goals. By contrast, employees pay close attention to what the organization thinks of them. The relationship between employers and employees is based on the norm of reciprocity and social exchange. Thus, management style and organizational culture are important. An employee of an organization that provides employees with abundant support for job resources, opportunities, and individualized consideration will be willing to stay [20]. On the contrary, employees will not want to stay in an organizational culture that discriminates, does not provide sufficient support, and treats members as fittings. This organization does not attach importance to human capital, which is a source of long-term performance because it is obsessed with short-term performance. This organization is not sustainable. Therefore, an employee's perception of the organization is very important.

In organizational support theory [21], perceived organizational support (POS) refers to the assurance that aid will be available from the organization when employees require it to carry out their job effectively and to deal with stressful situations [22]. Those who perceive organizational support undergo three psychological processes based on reciprocity. First, they will experience an obligation to achieve the organization's goals. Second, they will possess a social identity and a sense of belonging. Third, they will have a strong belief that the organization will reward their effort. Robblee [23] reported that POS weakened organizational strain, and Yoon, Han, and Seo [24] and Yoon and Lim [25] examined the negative correlation between POS and role stressors such as role conflict and role overload. All of these studies regard POS as a resource for dealing with external stress.

According to the JDR model and the buffer hypothesis [26], psychosocial resources weaken the relationship between stress and negative consequences such as burnout and depression. We expect employees in a supportive environment to be rich in resources. Specifically, they will believe that the organization will provide them with adequate support. They will treat hardships as a temporary obstacle or a difficulty that they will overcome, and they will maintain their loyalty due to the support provided to them by the organization [27]. Foley, Hang-Yue, and Lui [28] found a moderation effect of POS on the positive relationship between role overload and work-family conflict, while Bliese and Castro [29] 
examined the three-way multilevel interaction effect on job strain between role clarity, role overload, and perceived supervisor support. Based on the above described literature, we propose the following:

Hypothesis 2. Perceived organizational support will moderate the relationship between role overload and turnover intention, whereby low perceived organizational support will enhance the effect of role overload on turnover intention.

\subsection{Joint Moderation Effect of POS and Equity Sensitivity}

Role overload reflects an imbalance in a social exchange; POS mitigates the adverse effects of this imbalance [1,2]. However, the buffering effect of resources on the negative impact of job demands as posited by the JDR model has not been consistently demonstrated. A review study on job demands and support found that only 15 of 31 papers on this relationship reported results that fit the theory [30]. This relationship has not been statistically proven despite the theoretical consistency because individual characteristics have a strong influence on it [31]. As mentioned, equity sensitivity refers to individual responses to over-or under-reward situations. Huseman and colleagues [6] proposed that there are three types of individuals based on their degree of equity sensitivity: (1) benevolent, (2) equity sensitive, and (3) entitled. At one end of the spectrum, benevolent individuals value relationships [32]. They are altruistic enough to tolerate an inequity. They do not voice their opinion and do not exit their job. In other words, they are loyal and committed to the organization. Second, in the middle of the spectrum, equity-sensitive individuals value a fair equity ratio. They will complain about unfairness even if the rewards are great. Third, at the other end of the spectrum, entitled employees focus on their own outcomes. They tend to maximize their rewards and resolve their stress situations. Kickul and Lester [33] and King, Miles, and Day [34] examined the moderation effect of equity sensitivity on the relationship between psychological contract breaches, turnover intention, and organizational citizenship behavior. Shore, Sy, and Strauss [35] reported that leader responsiveness had a positive effect on job satisfaction, organizational commitment, organizational citizenship behavior, and job performance and a negative impact on turnover intention for employees with high equity sensitivity.

The effect of equity sensitivity will be strong when POS is low. High POS employees do not need to exit because they resolve the resource imbalance that comes from role overload through the support of the organization. When POS is low, however, they must choose whether to exit. Employees with high equity sensitivity want to resolve the problem by raising issues through formal procedures. However, employees who are insensitive to social exchange are less inclined to participate in complain procedures and thus cannot mitigate the adverse effects of role overload. They will have the greatest degree of turnover intention because they cannot use POS. We thus propose the following:

Hypothesis 3. The relationship between role overload and turnover intention is jointly moderated by POS and equity sensitivity. The relationship will be strongest under low POS and low equity sensitivity.

Figure 1 illustrates the research model and hypotheses in this study.

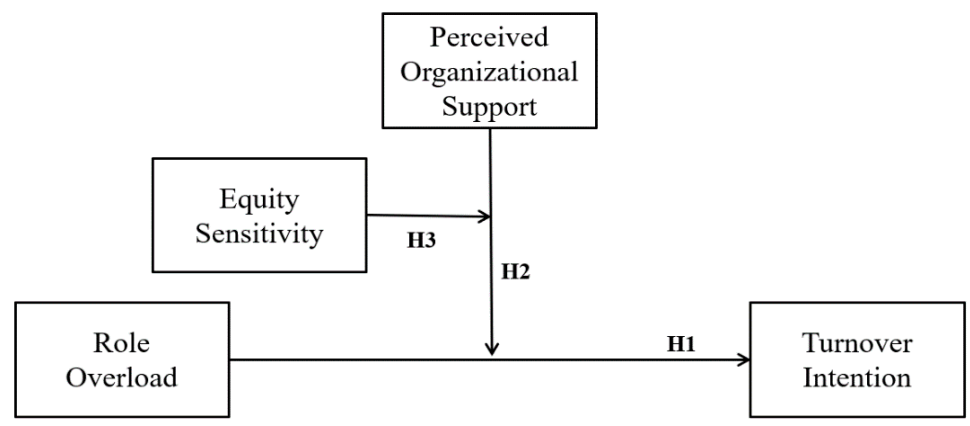

Figure 1. Research model and hypotheses. 


\section{Methods}

\subsection{Research Setting and Participants}

The participants in this study were 235 team members from 12 manufacturing companies located in South Korea. Data were obtained from 221 team members (a 94.04\% response rate). After 14 incomplete answers were excluded, 207 participants were analyzed. Employees from diverse functional areas of company participated in the survey. Participants were told that the university was conducting a study on working conditions and work behavior. Of the participants, $176(85.0 \%)$ were male and 31 (15.0\%) were female; $51(24.6 \%)$ had a college degree, 18 (8.7\%) had a Master's degree, and $18(8.7 \%)$ had a Doctoral degree; 27 (13\%) were aged under 30, 74 (35.7\%) were aged between 30 and 34, 63 $(30.4 \%)$ were aged between 35 and 39, 32 (15.5\%) were aged between 40 and 44, and $11(5.3 \%)$ were aged between 45 and 50. Participation in the study was voluntary and anonymity was assured.

\subsection{Measures}

For responses to all survey items, 7-point Likert scale estimates were used, ranging from 1 (strongly disagree) to 7 (strongly agree).

Role overload. We measured role overload with six items adapted from Ivancevich and Matteson [36]. Example items included "My job gets to me more than it should." and "I have too much work and too little time to do it in."

Equity sensitivity. Seven items were adapted from the entitlement dimension of the Equity Preference Questionnaire [37]. Example items included "I am most satisfied at work when I have to do as little as possible." and "At work, my greatest concern is whether or not I am doing the best job I can do."

Perceived organizational support. We adapted nine items from Eisenberger et al. [21]. Example items included "The organization really cares about my well-being." and "The organization would ignore any complaints from me."

Turnover intention. Six items developed from Becker [38] and Mobley [39] were adapted to assess employees' turnover intention. Example items included "I often think about quitting." and "It would take very little change in my present circumstances to cause me to leave this organization."

\subsection{Confirmatory Factor Analysis}

All measures were translated into Korean by two organizational behavior professors. To verify the discriminant validity of the translated measures, the factor structures of each variable were checked through confirmatory factor analysis (CFA). Table 1 depicts the results of the model fit comparison. The hypothesized four-factor model yielded an acceptable fit to the data $\left(\chi^{2}=709.78\right.$, $\mathrm{df}=344, p<0.01$, comparative fit index $=0.88$, Tucker-Lewis index $=0.86$, root mean square error of approximation $=0.07$ [40]). The alternative three-factor model, two-factor model, and one-factor model has a significantly worse fit than the hypothesized model.

Table 1. Results of Confirmatory Factor Analysis.

\begin{tabular}{|c|c|c|c|c|c|c|}
\hline Model & $x^{2}$ & df & $\Delta \chi^{2}(\Delta \mathrm{df})$ & CFI & TLI & RMSEA \\
\hline Hypothesized four-factor model & 709.78 & 344 & - & 0.88 & 0.86 & 0.07 \\
\hline Three-factor model (combining moderators) & 1126.35 & 347 & $416.57(3)$ & 0.70 & 0.67 & 0.11 \\
\hline Two-factor model (combining IV and Moderators) & 1503.00 & 349 & $793.22(5)$ & 0.61 & 0.58 & 0.13 \\
\hline One-factor model (combining all variables) & 1737.19 & 350 & $1027.41(6)$ & 0.53 & 0.49 & 0.14 \\
\hline
\end{tabular}

Note: $\mathrm{N}=207$. IV = independent variable; $\mathrm{CFI}=$ comparative fit index; TLI = Tucker-Lewis index; RMSEA = root mean square error of approximation.

\section{Results}

Table 2 presents the descriptive statistics and correlations. Internal consistency reliabilities are in parentheses on the diagonal, when applicable. Role overload is significantly correlated with all the 
moderators $(\mathrm{r}=0.40, p<0.01$ for equity sensitivity, and $\mathrm{r}=-0.25, p<0.01$ for perceived organizational support) and the dependent variable $(\mathrm{r}=0.44, p<0.01)$. Perceived organizational support $(\mathrm{r}=-0.46$, $p<0.01)$ is negatively correlated and equity sensitivity $(r=0.40, p<0.01)$ is positively correlated with turnover intention, as expected.

Table 2. Means, standard deviations, and correlations among study variables.

\begin{tabular}{ccccccccc}
\hline & Variable & Mean & SD & $\mathbf{1}$ & $\mathbf{2}$ & $\mathbf{3}$ & $\mathbf{4}$ & $\mathbf{5}$ \\
\hline 1 & Gender & 0.15 & 0.36 & - & & & & \\
2 & Role Overload & 4.14 & 0.91 & -0.03 & $(0.82)$ & & & \\
3 & Equity Sensitivity & 3.58 & 1.17 & 0.04 & $0.40^{* *}$ & $(0.91)$ & & \\
4 & POS & 3.88 & 0.88 & -0.05 & $-0.25^{* *}$ & $-0.44^{* *}$ & $(0.87)$ & \\
5 & Turnover Intention & 4.16 & 0.99 & -0.04 & $0.44^{* *}$ & $0.40^{* *}$ & $-0.46^{* *}$ & $(0.84)$ \\
\hline \multicolumn{7}{c}{$p<0.05,{ }^{* *} p<0.01}$.
\end{tabular}

We conducted several hierarchical regression analyses to test our hypotheses. We controlled for gender in step 1 of all the regression models. Hypothesis 1 posits the positive effect of role overload on turnover intention. Table 3 shows the significant and positive regression coefficient for role overload on turnover intention ( $b=0.47, p<0.01$ ). Thus, Hypothesis 1 is supported.

Table 3. Results for Hypothesis 1.

\begin{tabular}{ccccc}
\hline & \multicolumn{2}{c}{ Step 1 } & \multicolumn{2}{c}{ Step 2 } \\
\hline Predictor & $\mathrm{b}$ & $\mathrm{SE}$ & $\mathrm{b}$ & $\mathrm{SE}$ \\
Constant & $4.28^{* *}$ & 0.23 & $2.28 *$ & 0.36 \\
Gender & -0.11 & 0.19 & -0.07 & 0.17 \\
Role Overload & \multicolumn{3}{c}{$0.47^{* *}$} & 0.07 \\
$\mathrm{R}^{2}$ & \multicolumn{2}{c}{0.01} & \multicolumn{2}{c}{0.19} \\
$\Delta \mathrm{R}^{2}$ & & \multicolumn{2}{c}{$0.18^{* *}$} \\
\hline${ }^{*} p<0.05,{ }^{* *} p<0.01 ; \mathrm{SE}=$ standard error.
\end{tabular}

Hypothesis 2 proposes the moderating effect of POS on the relation between role overload and turnover intention. As presented in Table 4, the regression coefficient of the interaction term of role overload and POS is not significant. Thus, Hypothesis 2 is not supported.

Table 4. Results for Hypothesis 2.

\begin{tabular}{|c|c|c|c|c|c|c|}
\hline & \multicolumn{2}{|c|}{ Step 1} & \multicolumn{2}{|c|}{ Step 2} & \multicolumn{2}{|c|}{ Step3 } \\
\hline Predictor & $\mathrm{b}$ & SE & $\mathrm{b}$ & SE & $\mathrm{b}$ & SE \\
\hline Constant & $4.28^{* *}$ & 0.23 & $4.31 * *$ & 0.19 & $4.31^{* *}$ & 0.19 \\
\hline Gender & -0.11 & 0.19 & -0.13 & 0.16 & -0.13 & 0.16 \\
\hline Role Overload (RO) & & & $0.37^{* *}$ & 0.06 & $0.37^{* *}$ & 0.06 \\
\hline POS & & & $-0.43^{* *}$ & 0.07 & $-0.42^{* *}$ & 0.07 \\
\hline $\mathrm{RO} \times \mathrm{POS}$ & & & & & 0.03 & 0.06 \\
\hline $\mathrm{R}^{2}$ & \multicolumn{2}{|c|}{0.01} & \multicolumn{2}{|c|}{0.33} & \multicolumn{2}{|c|}{0.34} \\
\hline$\Delta \mathrm{R}^{2}$ & & & \multicolumn{2}{|c|}{$0.32 * *$} & \multicolumn{2}{|c|}{$0.01 * *$} \\
\hline
\end{tabular}

For Hypothesis 3, we expected a three-way interaction effect of role overload, POS, and equity sensitivity on turnover intention. As shown in Table 5, the interaction term explains an additional $2 \%$ variance in turnover intention $(\Delta \mathrm{R}=0.02, p<0.01)$. In addition, the regression coefficient of the interaction term is significant and positive $(b=0.12, p<0.05)$. Thus, Hypothesis 3 is supported. 
Table 5. Results for Hypothesis 4 .

\begin{tabular}{|c|c|c|c|c|c|c|c|c|}
\hline & \multicolumn{2}{|c|}{ Step 1} & \multicolumn{2}{|c|}{ Step 2} & \multicolumn{2}{|c|}{ Step 3} & \multicolumn{2}{|c|}{ Step 4} \\
\hline Predictor & $\mathrm{b}$ & SE & $\mathrm{b}$ & SE & $\mathrm{b}$ & SE & $\mathrm{b}$ & SE \\
\hline Constant & $4.28 * *$ & 0.23 & $4.33 * *$ & 0.19 & $4.37^{* *}$ & 0.19 & $4.43 * *$ & 0.19 \\
\hline Gender & -0.11 & 0.19 & -0.14 & 0.16 & -0.14 & 0.16 & -0.18 & 0.16 \\
\hline Role Overload (RO) & & & $0.32 * *$ & 0.07 & $0.31 * *$ & 0.07 & $0.34 * *$ & 0.07 \\
\hline Equity Sensitivity (ES) & & & $0.12 *$ & 0.06 & $0.12 *$ & 0.06 & $0.14 *$ & 0.06 \\
\hline Perceived Organizational Support (POS) & & & $-0.37^{* *}$ & 0.07 & $-0.35^{* *}$ & 0.07 & $-0.41^{* *}$ & 0.08 \\
\hline $\mathrm{RO} \times \mathrm{ES}$ & & & & & -0.06 & 0.06 & -0.12 & 0.06 \\
\hline $\mathrm{RO} \times \mathrm{POS}$ & & & & & -0.04 & 0.07 & -0.01 & 0.07 \\
\hline $\mathrm{ES} \times \mathrm{POS}$ & & & & & 0.07 & 0.06 & 0.07 & 0.06 \\
\hline $\mathrm{RO} \times \mathrm{ES} \times \mathrm{POS}$ & & & & & & & $0.12 *$ & 0.05 \\
\hline $\mathrm{R}^{2}$ & \multicolumn{2}{|c|}{0.01} & \multicolumn{2}{|c|}{0.34} & \multicolumn{2}{|c|}{0.35} & \multicolumn{2}{|c|}{0.37} \\
\hline$\Delta \mathrm{R}^{2}$ & & & \multicolumn{2}{|c|}{$0.33 * *$} & \multicolumn{2}{|c|}{$0.01 * *$} & \multicolumn{2}{|c|}{$0.02 * *$} \\
\hline
\end{tabular}

To further test Hypothesis 3, we plotted a graph and conducted a slope difference test [41]. As shown in Table 6 and Figure 2, the slope of Group 4 (low equity sensitivity and low POS) is significantly different from those of other groups. As hypothesized, the relations between role overload and turnover intention are strongest under low equity sensitivity and low POS. These results also support Hypothesis 3.

Table 6. Slope difference test: Standard error of differences between all six pairs of slopes and associated test statistics.

\begin{tabular}{ccc}
\hline Pair of Slopes & $\begin{array}{c}\boldsymbol{t} \text {-Value for } \\
\text { Slope Difference }\end{array}$ & $\begin{array}{c}\boldsymbol{p} \text {-Value for } \\
\text { Slope Difference }\end{array}$ \\
\hline Group 1 and Group 2 & 1.32 & 0.19 \\
Group 1 and Group 3 & -0.48 & 0.63 \\
Group 1 and Group 4 & -2.01 & 0.05 \\
Group 2 and Group 3 & -1.77 & 0.08 \\
Group 2 and Group 4 & -2.74 & 0.01 \\
Group 3 and Group 4 & -2.26 & 0.03 \\
\hline
\end{tabular}

Note: Group 1: high equity sensitivity, high perceived organizational support; Group 2: high equity sensitivity, low perceived organizational support; Group 3: low equity sensitivity, high perceived organizational support; Group 4: low equity sensitivity, low perceived organizational support.

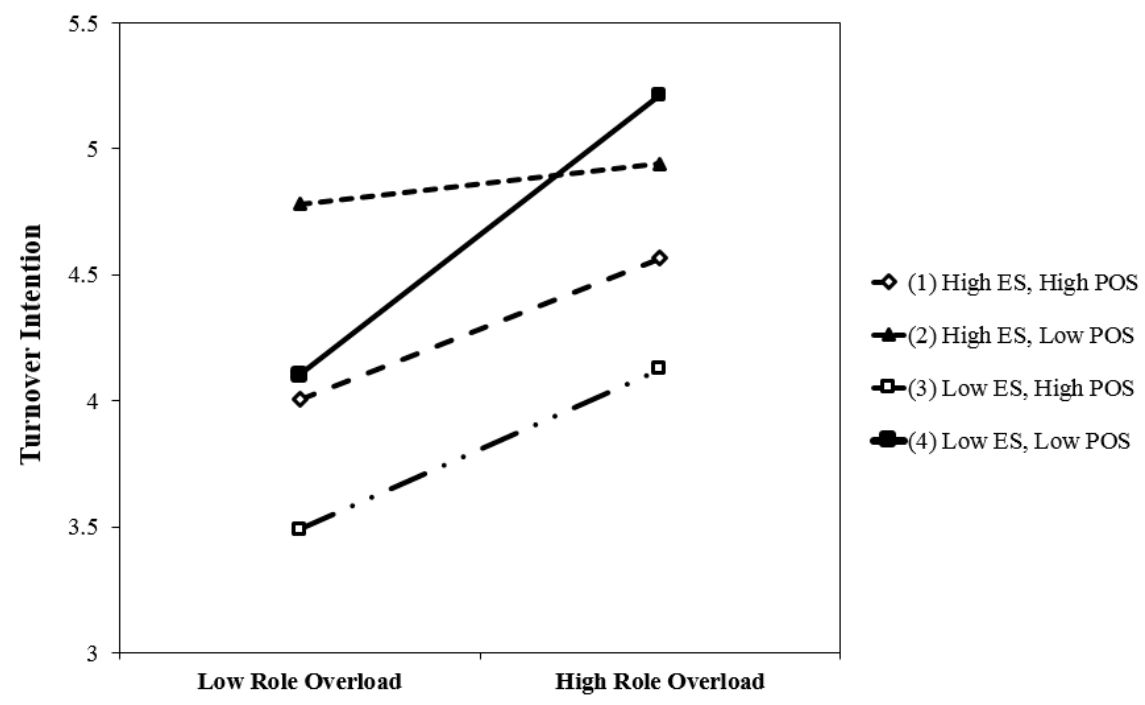

Figure 2. Three-way interaction graph of role overload, equity sensitivity, and perceived organizational support predicting turnover intention. Note. ES = equity sensitivity; POS = perceived organizational support. 


\section{Discussion}

This study examined the direct and moderating effects of role overload, POS, and equity sensitivity on turnover intention. As hypothesized, the results on the main effect of role overload on turnover intention were consistent with JDR theory, confirming the strain effect of role overload: Employees who lose their cognitive and psychosocial resources will increase their turnover intention. However, our hypothesis on the buffer effect of POS on the main relationship was rejected. We found an activation effect of equity sensitivity in the buffer hypothesis only by proving a three-way interaction in which employees with low equity sensitivity working in a less-supportive climate will most likely exit the organization without raising issues through formal procedures.

\subsection{Theoretical and Practical Implications}

This study expands on JDR theories by simultaneously considering the buffer and strain hypotheses in the role stress-turnover relationship. We study turnover intention rather than the theories' conventional dependent variables such as burnout or depression. To our knowledge, this is the first study to link equity sensitivity to the buffer and strain hypotheses. This study identified the key role of equity sensitivity in the buffer hypothesis by showing that a three-way interaction effect occurs even when the buffering effect of POS is insignificant. Additionally, we build on the organizational fairness literature by providing a foundation for understanding individual differences in attitudes to fairness. The literature has mainly focused on the justice perception of individuals, such as distributive justice, procedural justice, and interactional justice [5], but our results indicate that personal traits, such as equity sensitivity, constitute the core issue in fairness research.

This study has several practical implications for organizations. Employees require a clear role and significant resources to meet their job demands. A chronic resource shortage tends to create role overload. In addition, an overloaded role affects employees' turnover intention, which weakens their short-term competitiveness as well as their long-term sustainability. This study shows that a supportive climate and employees' equity sensitivity are key. If organizations cannot avoid resource shortages, they should ensure that employees' roles are clear and that their environment is supportive. At a minimum, they should understand the equity sensitivity of their employees. Our findings also suggest that managers should realize that the psychological response to the situation varies from employee to employee. Employees who are sensitive to equity imbalance and those who are not respond differently to role overload and differ in how they respond to organizational support.

\subsection{Limitations and Future Research}

Our study had several limitations. First, our research setting is South Korea, which has a highly collectivist culture and where most manufacturing companies are subcontractors of large enterprises. These cultural specificities may decrease the generalizability of our results. The corporate culture of Korea is strong, and the external labor market is underdeveloped. Therefore, turnover is not active, and the turnover intention of members is not high. Social perception of overwork is also generous. Cross-validation in other cultures is thus essential. On the other hand, the hypothesis of this paper was supported even in such a negative environment. Therefore, it is likely to be supported more strongly in western culture or more supportive cultures. Second, considering the cross-sectional design of the study, its simultaneous measurement may cause common method bias [42]. We checked the factor structure of the five-factor model involving a single latent variable to address the impact of the common methods bias. Although the results suggest that the influence of common method variance on our results was not serious, any potential common method bias could be avoided by collecting the data longitudinally. Third, our variables have relatively high correlations. The correlation between POS and turnover intention was $0.44(p<0.01)$, and the correlation between role overload and equity sensitivity was $0.40(p<0.01)$. These could confound the effect of the regression equations [43]. 
We concentrated on role overload. Future research should examine other role stressors, such as role conflict and role ambiguity. Role conflict and ambiguity could also be included, as they are considered the main causes of strain. Future research could also study the mediation process. According to self-determination theory [44], role stressors aggravate employee motivation. Thus, work engagement could be a mediator in the relationships we examined. Finally, psychological wellbeing could be considered as a potential dependent variable. Employee happiness is considered a major organizational goal by the "positive psychology movement" [45]. Employees' happiness must be properly managed to maintain an effective workforce.

Author Contributions: Conceptualization, C.Y.K.; data curation, J.H.L.; resources, J.H.L.; supervision, S.Y.S.; writing - original draft, C.Y.K.; Writing—review and editing, S.Y.S.

Funding: This research received no external funding.

Conflicts of Interest: The authors declare no conflict of interest.

\section{References}

1. Bakker, A.B.; Demerouti, E.; Euwema, M.C. Job resources buffer the impact of job demands on burnout. J. Occup. Health Psychol. 2005, 10, 170-180. [CrossRef] [PubMed]

2. Demerouti, E.; Bakker, A.B.; Nachreiner, F.; Schaufeli, W.B. The job demands-resources model of burnout. J. Appl. Psychol. 2001, 86, 499-512. [CrossRef] [PubMed]

3. Kobasa, S.C.; Puccetti, M.C. Personality and social resources in stress resistance. J. Personal. Soc. Psychol. 1983, 45, 839-850. [CrossRef]

4. Cropanzano, R.; Mitchell, M. Social exchange theory: An interdisciplinary review. J. Manag. 2005, 31, 874-900. [CrossRef]

5. Colquitt, J.A.; Conlon, D.E.; Wesson, M.J.; Porter, C.O.L.H.; Ng, K.Y. Justice at the millennium: A meta-analytic review of 25 years of organizational justice research. J. Appl. Psychol. 2001, 86, 425-445. [CrossRef] [PubMed]

6. Huseman, R.C.; Hatfield, J.D.; Miles, E.W. A new perspective on equity theory: The equity sensitivity construct. Acad. Manag. Rev. 1987, 12, 222-234. [CrossRef]

7. O'neill, B.S.; Mone, M.A. Investigating equity sensitivity as a moderator of relations between self-efficacy and workplace attitudes. J. Appl. Psychol. 1998, 83, 805-816. [CrossRef]

8. Adams, J.S. Towards an understanding of inequity. J. Abnorm. Soc. Psychol. 1963, 67, 422-436. [CrossRef]

9. Avery, D.R.; Tonidandel, S.; Volpone, S.D.; Raghuram, A. Overworked in America? How work hours, immigrant status, and interpersonal justice affect perceived work overload. J. Manag. Psychol. 2010, 25, 133-147. [CrossRef]

10. St-Pierre, I.; Holmes, D. The relationship between organizational justice and workplace aggression. J. Adv. Nurs. 2010, 66, 1169-1182. [CrossRef]

11. Lazarus, R.S.; Folkman, S. Coping and adaptation. In The Handbook of Behavioral Medicine; Basic Books: New York, NY, USA, 1984; pp. 282-325.

12. Häusser, J.A.; Mojzisch, A.; Niesel, M.; Schulz-Hardt, S. Ten years on: A review of recent research on the Job Demand-Control (-Support) model and psychological well-being. Work Stress 2010, 24, 1-35. [CrossRef]

13. Sales, S.M. Some effects of role overload and role underload. Organ. Behav. Hum. Perform. 1970, 5, 592-608. [CrossRef]

14. Shultz, K.S.; Wang, M.; Olson, D.A. Role overload and underload in relation to occupational stress and health. Stress Health 2010, 26, 99-111. [CrossRef]

15. Karimi, R.; Omar, Z.B.; Alipour, F.; Karimi, Z. The influence of role overload, role conflict, and role ambiguity on occupational stress among nurses in selected Iranian hospitals. Int. J. Asian Soc. Sci. 2014, 4, 34-40.

16. Malik, M.I.; Sajjad, M.; Hyder, S.; Ahmad, M.S.; Ahmed, J.; Hussain, S. Role overload: A cause of diminishing employee retention and productivity. Middle-East J. Sci. Res. 2013, 18, 1573-1577. [CrossRef]

17. Kim, A.; Barak, M.E.M. The mediating roles of leader-member exchange and perceived organizational support in the role stress-turnover intention relationship among child welfare workers: A longitudinal analysis. Child. Youth Serv. Rev. 2015, 52, 135-143. [CrossRef] 
18. Cho, J.E.; Choi, H.C.; Lee, W.J. An empirical investigation of the relationship between role stressors, emotional exhaustion and turnover intention in the airline industry. Asia Pac. J. Tourism Res. 2014, 19, 1023-1043. [CrossRef]

19. Shupe, E.I.; Wambaugh, S.K.; Bramble, R.J. Role-related stress experienced by academic librarians. J. Acad. Librariansh. 2015, 41, 264-269. [CrossRef]

20. Rafferty, A.; Griffin, M. Perceptions of Organizational Change: A Stress and Coping Perspective. J. Appl. Psychol. 2006, 91, 1154-1162. [CrossRef]

21. Eisenberger, R.; Huntington, R.; Hutchinson, S.; Sowa, D. Perceived organizational support. J. Appl. Psychol. 1986, 71, 500-507. [CrossRef]

22. He, H.; Pham, H.Q.; Baruch, Y.; Zhu, W. Perceived organizational support and organizational identification: Joint moderating effects of employee exchange ideology and employee investment. Int. J. Hum. Resour. Manag. 2014, 25, 2772-2795. [CrossRef]

23. Robblee, M. Confronting the Threat of Organizational Downsizing: Coping and Health. Master's Thesis, Carleton University, Ottawa, ON, Canada, 1998. Unpublished work.

24. Yoon, J.; Han, N.-C.; Seo, Y.-J. Sense of control among hospital employees: An assessment of choice process, empowerment and buffering hypotheses. J. Appl. Psychol. 1996, 26, 686-716. [CrossRef]

25. Yoon, J.; Lim, J.C. Organizational support in the workplace: The case of Korean hospital employees. Hum. Relat. 1999, 52, 923-945. [CrossRef]

26. Cohen, S.; Wills, T.A. Stress, social support, and the buffering hypothesis. Psychol. Bull. 1985, 98, $310-357$. [CrossRef] [PubMed]

27. Seligman, M.E.P. Authentic Happiness: Using the New Positive Psychology to Realize Your Potential for Lasting Fulfillment; Free Press: New York, NY, USA, 2002.

28. Foley, S.; Hang-Yue, N.; Lui, S. The effects of work stressors, perceived organizational support, and gender on work-family conflict in Hong Kong. Asia Pac. J. Manag. 2005, 22, 237-256. [CrossRef]

29. Bliese, P.D.; Castro, C.A. Role clarity, work overload and organizational support: Multilevel evidence of the importance of support. Work Stress 2000, 14, 65-73. [CrossRef]

30. Van der Doef, M.; Maes, S. The job demand-control (-support) model and psychological well-being: A review of 20 years of empirical research. Work Stress 1999, 13, 87-114. [CrossRef]

31. Parkes, K.R. Personality and coping as moderators of work stress processes: Models, methods and measures. Work Stress 1994, 8, 110-129. [CrossRef]

32. Miles, E.; Hatfield, J.; Huseman, R. Equity sensitivity and outcome importance. J. Organ. Behav. 1994, 15, 585-596. [CrossRef]

33. Kickul, J.; Lester, S.W. Broken promises: Equity sensitivity as a moderator between psychological contract breach and employee attitudes and behavior. J. Bus. Psychol. 2001, 16, 191-217. [CrossRef]

34. King, W.C.; Miles, E.W.; Day, D.D. A test and refinement of the equity sensitivity construct. J. Organ. Behav. 1993, 14, 301-317. [CrossRef]

35. Shore, T.; Sy, T.; Strauss, J. Leader responsiveness, equity sensitivity, and employee attitudes and behavior. J. Bus. Psychol. 2006, 21, 227-241. [CrossRef]

36. Ivancevich, J.M.; Matteson, M.T. Stress and Work, Scott; Foresman and Company: Chicago, IL, USA, 1980.

37. Sauley, K.S.; Bedeian, A.G. Equity sensitivity: Construction of a measure and examination of its psychometric properties. J. Manag. 2000, 26, 885-910. [CrossRef]

38. Becker, T.E. Foci and bases of commitment: Are they distinctions worth making. Acad. Manag. J. 1992, 35, 232-244. [CrossRef]

39. Mobley, W.H. Employee Turnover, Causes, Consequences, and Control; Addison-Wesley: Reading, MA, USA, 1982; ISBN 9780201046731.

40. Hu, L.T.; Bentler, P.M. Cutoff criteria for fit indexes in covariance structure analysis: Conventional criteria versus new alternatives. Struct. Eq. Model. Multidiscip. J. 1999, 6, 1-55. [CrossRef]

41. Dawson, J.F.; Richter, A.W. Probing three-way interactions in moderated multiple regression: Development and application of a slope difference test. J. Appl. Psychol. 2006, 91, 917-926. [CrossRef] [PubMed]

42. Podsakoff, P.M.; MacKenzie, S.B.; Lee, J.Y.; Podsakoff, N.P. Common method biases in behavioral research: A critical review of the literature and recommended remedies. J. Appl. Psychol. 2003, 88, 879-903. [CrossRef] [PubMed] 
43. Edwards, J.R. Alternatives to difference scores: Polynomial regression and response surface methodology. In Advances in Measurement and Data Analysis; Drasgow, F., Schmitt, N.W., Eds.; Jossey-Bass: San Francisco, CA, USA, 2002; pp. 350-400.

44. Ryan, R.M.; Deci, E.L. Self-determination theory and the facilitation of intrinsic motivation, social development, and well-being. Am. Psychol. 2000, 55, 68-78. [CrossRef] [PubMed]

45. Seligman, M.E. Positive psychology, positive prevention, and positive therapy. Handb. Posit. Psychol. 2002, 2, 3-12. article distributed under the terms and conditions of the Creative Commons Attribution (CC BY) license (http://creativecommons.org/licenses/by/4.0/). 